Original Research

\title{
Field Experiments on Reducing Pollutants in Agricultural-Drained Water Using Soil-Vegetation Buffer Strips
}

\author{
Yuanyuan $\mathrm{Li}^{1,2,3}$, Xiaohou Shao ${ }^{1,2 *}$, Zhuping Sheng ${ }^{3}$ \\ ${ }^{1}$ Key Laboratory of Efficient Irrigation-Drainage and Agricultural Soil-Water Environment in Southern China, \\ Hohai University, 210098, P.R. China \\ ${ }^{2}$ College of Water Conservancy and Hydropower, Hohai University, \\ Nanjing, 210098, P.R. China \\ ${ }^{3}$ Texas AgriLife Research Center at El Paso, \\ Texas A\&M University, 79927, USA
}

Received: 28 April 2015

Accepted: 3 December 2015

\begin{abstract}
Agricultural drainage is one of the leading contributors to agricultural non-point source (AGNPS) pollution in China. It is difficult to treat due to its dispersed nature. In recent years, although agricultural drainage water has been reused in agricultural production, its poor quality has limited its potential utilization. To optimize its reuse, we designed and tested a treatment system for agricultural-drained water compromising a vegetation buffer, slopes (plant filter), a water collection area, and a soil-retention wall in Hengxi town, Nanjing, Jiangsu Province, China. By exploiting the soil-vegetation buffer strips, nitrogen and phosphorus in the paddy field's surface drainage are expected to be reduced dramatically. Test results suggest that after applying basal fertilizer, the removal rates of total nitrogen by the soil-vegetation buffer strips are $90.6 \%$ and $95.2 \%$ for controlled and conventional irrigation-drainage treatments, respectively. In addition, the removal rates of dissolved nitrogen are $92 \%$ and $90.7 \%$ (controlled and conventional), the removal rates of total phosphorus are $94.2 \%$ and $92.9 \%$, and for dissolved phosphorus, the rates are $94.4 \%$ and $95 \%$, respectively. These data indicate that drainage water from a paddy field that has been treated through the constructed system could reach the standard of National Class II with two irrigation-drainage methods, while for control treatments water quality can only reach Class V, which is severely contaminated. With this system, the reuse of agricultural water resources could be achieved, which will undoubtedly provide a great potential for agricultural water management in southern China, as well as achieving excellent overall ecological benefits.
\end{abstract}

Keywords: soil-vegetation buffer strips, controlled irrigation-drainage, rainfall, water quality evaluation

*e-mail: shaoxiaohou@163.com 


\section{Introduction}

As Chemical fertilizer application increases in the farmland ecosystem, nitrogen and phosphorus losses in the field through surface runoff and seepage are increasing annually, resulting in water eutrophication and groundwater contamination [1-4]. Rice is the main crop in southern China, grown primarily in rainy seasons with frequent rainstorms during the growth period. While farmland drainage occurs, nutrient loss takes place all along. Thus agricultural drainage is a major contributing factor to agricultural non-point source (AGNPS) pollution, due to the agricultural inputs of nitrogen and phosphorus nutrients, toxic substances, heavy metals, and organics from fertilizers or pesticides. Agricultural non-point source pollution is difficult to treat in practice because of its decentralized nature [5-8]. With respect to paddy fields, the main avenues for fertilizer loss are surface drainage and leakage to groundwater [9-13]. Therefore, many researchers are conducting extensive studies that look at the effects of drainage systems on water quality, including the transport of agricultural chemicals to surface waters and shallow groundwater aquifers.

Controlled irrigation-drainage technology is a kind of water-saving irrigation technology that can also reduce non-point source pollution in paddy fields through reasonable rainfall utilization, leakage and evaporation regulation, etc. $[14,15]$. A thin water layer is kept in the paddy field surface from transplant to revival. The irrigation-drainage time and irrigation-drainage quota are then determined according to soil moisture in the paddy root zone. The upper limit of soil moisture control is saturated water content, while the lower limit is $60-80 \%$ of the saturated water content according to growth stages $[16,17]$. This measurement could result in a soil water deficit and change rice physiological and ecological activities, which improves root water, fertilizer, air, and heat conditions, thus promoting crop production.

In addition, artificial wetlands and buffer strips are identified as effective measures for non-point pollution control [18-20] because of its crucial role in the retention of nitrogen and phosphorus released in large quantities from agricultural farmland inputs. Artificial wetland systems are being utilized for the treatment and buffering of effluent and runoff water in recycling applications $[21,22]$. Through growing some specific plants that are prone to absorbing pollutants due to their intrinsic properties, the polluted body of water can be treated, while simultaneously the large specific surface areas of fillers in the artificial wetlands (such as gravels) allows being effective for pollution removal. These cases are ecofriendly and are widely accepted [23-26].

Our study compares the pollution-reducing effects of two irrigation-drainage measurements in farmland followed by a combination study of the agricultural drainage system and the soil-vegetation buffer strips, a kind of wetland system, in order to optimize a treatment and reuse system for agricultural drainage water reuse. We demonstrated that this system was effective for controlling
AGNPS pollution with nitrogen and phosphorus, which has both good ecological benefits and promotion and application values.

\section{Materials and Methods}

\section{Study Area}

The experiments were carried out at Vegetables (Flowers) Scientific Institute (latitude $32^{\circ} 13^{\prime} \mathrm{N}$, longitude $119^{\circ} 04^{\prime} \mathrm{E}$ ) in Hengxi, Nanjing, Jiangsu province, China during the rice growing season, from June to October 2012. The experimental site was located in a subtropical humid region with an average annual rainfall of approximately $1,107 \mathrm{~mm}$ in the rainy season, starting from the end of June and continuing until the middle of September. However, average yearly evaporation was around $1,473 \mathrm{~mm}$, with 2,017 sunshine hours, an average annual temperature of about $15.7^{\circ} \mathrm{C}, 81 \%$ maximum average humidity, and wind speed of $19.8 \mathrm{~m} / \mathrm{s}$.

The paddy field is not intensively cultivated, usually with only one crop annually. The pre-test analysis showed that the soil was clay loam with a $\mathrm{pH}$ of 5.87 , a bulk density of $1.35 \mathrm{~g} \mathrm{~cm}^{-3}$, a weight soil moisture content of $28 \%$, organic matter $\left(21.7 \mathrm{~g} \mathrm{~kg}^{-1}\right)$, hydrolysis nitrogen (86.5 $\left.\mathrm{mg} \mathrm{kg}^{-1}\right)$, and available phosphorus $\left(25.3 \mathrm{mg} \mathrm{kg}^{-1}\right)$ at a soil depth of 0-60 cm.

\section{Experimental Design}

The experiment was designed using conventional fertilizer mode combined with two irrigation-drainage techniques: controlled irrigation-drainage (S1) and conventional irrigation-drainage (S2). Two separate control areas without the treatment of soil-buffer strips (CK1, CK2) were designed for the comparison. Each plot was designed using the random block method with three replications of equal size $(2 \mathrm{~m} \times 5 \mathrm{~m} \times 0.3 \mathrm{~m})$. Each of the treatment fields had all of the above-mentioned soil properties. In the experimental plots, PVC pipes ( $\mathrm{D}=0.2 \mathrm{~m}$, $\mathrm{D}$ : diameter) were installed for surface drainage, and each plot was irrigated and drained alone. There was also a water meter and a lysimeter $(\mathrm{D}=0.6 \mathrm{~m}$, D: diameter), and other facilities were set separately. As a consequence, discharge could be recorded through the water meters.

Additionally, a measurement zone $(1 \mathrm{~m} \times 1.5 \mathrm{~m} \times 0.8 \mathrm{~m})$ was designed in each plot for observing the groundwater level and mixed-layer water quality changes. When there was rain or the cropland needed to drain, water from the surface drainage pipe needed to be sampled for monitoring; otherwise, the mixed water in the measurement zone was sampled. The experimental field layout is shown in Fig.1.

\section{Soil Moisture}

Data of soil moisture (water level and soil water content) under two irrigation-drainage regimes at different 


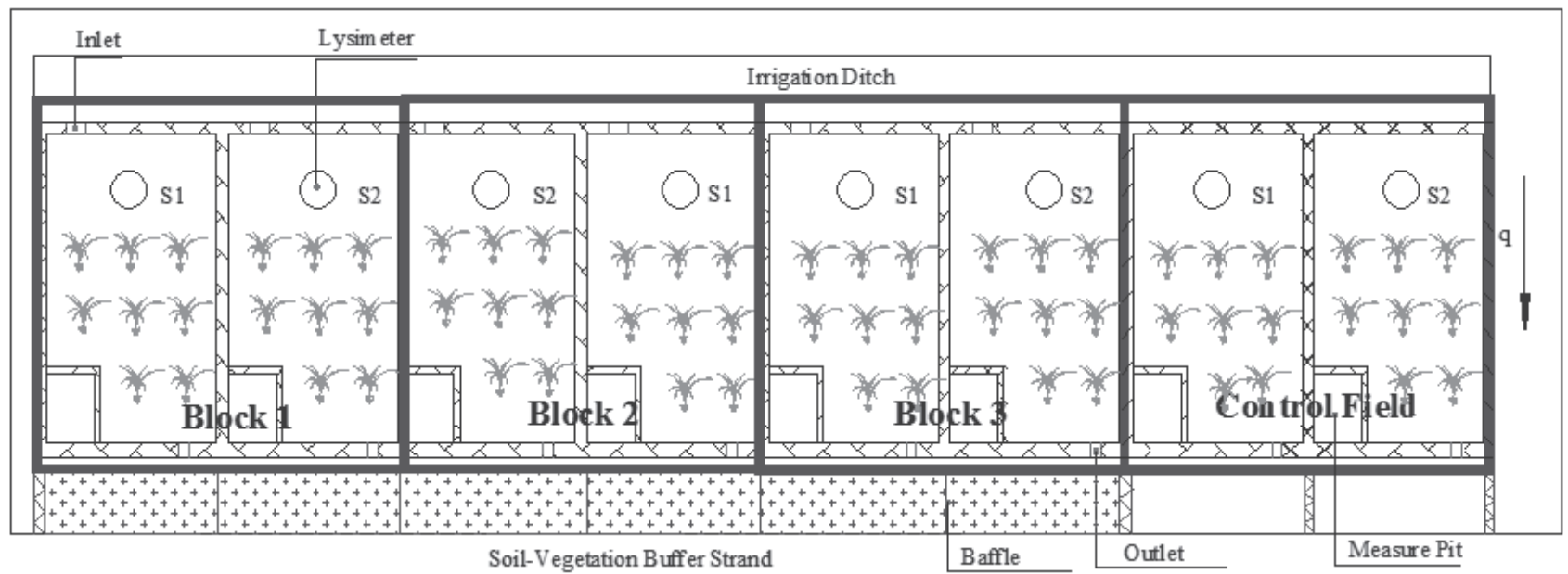

Fig. 1. View of experimental field in Nanjing, Jiangsu, China.

growth stages of paddy rice are shown in Table 1. In control areas, conventional irrigation-drainage management was carried out. The irrigation and drainage water amount is controlled according to this table.

Water balance of the paddy field during the entire growth period is shown in Table 2 .

\section{Cultural Practices}

Rice (cv. Kaohsiung, Taiwan 139) was chosen for transplantation on June 20, 2012, with a plant density between 703,500 and 825,000 seedlings per $\mathrm{hm}^{2}$. Meanwhile, compound fertilizer (nutrients content $\geq 45 \%$ ) at a rate of $750 \mathrm{~kg} \mathrm{hm}^{-2}$ was applied in the field as the base fertilizer, with nitrogen at a rate of $112.5 \mathrm{~kg} \mathrm{hm}^{-2}$ and phosphorus at a rate of $249.1 \mathrm{~kg} \mathrm{hm}^{-2}$. During the growth period of paddy rice, the two dressing fertilizations were applied at tillering stage and heading-flowering stage. Both of them were urea at the rate of $225 \mathrm{~kg} \mathrm{hm}^{-2}$ and 105 $\mathrm{kg} \mathrm{hm}{ }^{-2}$, respectively. Rice was harvest on October 30, 2012. The pests (paddy rice borer and rice plant hopper) in the rice growth stages were treated by spraying pesticide. All other agricultural practices, such as tillage, plant protection, weeding, and worming were maintained the same for all treatments.

\section{Design for Soil-Vegetation Buffer Strips}

Next to the paddy field, soil-vegetation buffer strips were constructed at the end of the surface drainage pipe, which was about $10 \mathrm{~cm}$ lower than the paddy field. This ensured a certain depth of the field surface water layer in the buffer that was favorable for plant growth. Moreover, the water layer depth needed to allow the water to stay for a particular length of time. Inside the buffer strips, baffles were set between the treatments to reduce the potential for interference. In the control area, without buffer strips give rise to that the drained water only stayed in the area and

Table 1. Controlling targets of soil moisture during paddy rice growth stages in two irrigation regimes.

\begin{tabular}{|c|c|c|c|c|c|c|c|c|}
\hline \multirow{2}{*}{ Treatment } & \multirow{2}{*}{ Returning green } & \multicolumn{3}{|c|}{ Tillering } & \multicolumn{2}{|c|}{ Jointing-Booting } & \multirow{2}{*}{$\begin{array}{c}\text { Heading- } \\
\text { Flowering }\end{array}$} & Milking \\
\cline { 3 - 7 } & & Early & Mid-term & Late & Early & Late & & \\
\hline \multirow{2}{*}{ S1 } & $100 \%$ & $70 \%$ & $65 \%$ & $60 \%$ & $80 \%$ & $80 \%$ & $80 \%$ & $65 \%$ \\
& $(5-25)$ & $(0-50)$ & $(0-50)$ & $(0-0)$ & $(0-70)$ & $(0-70)$ & $(0-70)$ & $(0-20)$ \\
\hline \multirow{2}{*}{ S2 } & $100 \%$ & $100 \%$ & $100 \%$ & $60 \%$ & $100 \%$ & $100 \%$ & $100 \%$ & $100 \%$ \\
& $(30-50)$ & $(0-30)$ & $(15-30)$ & $(0-0)$ & $(30-50)$ & $(30-50)$ & $(30-50)$ & $(15-30)$ \\
\hline
\end{tabular}

Notes: 1) The first number is a percentage of the saturated water content of soil; 2) the numbers in parentheses are the range of the storage depth of surface water in $\mathrm{mm}$ in the paddy field.

Table 2. Water balance in paddy field (2012).

\begin{tabular}{|c|c|c|c|c|c|c|}
\hline Treatment & $\begin{array}{c}\text { Effective Rainfall } \\
(\mathrm{mm})\end{array}$ & $\begin{array}{c}\text { Irrigation } \\
(\mathrm{mm})\end{array}$ & $\begin{array}{c}\text { Drainage } \\
(\mathrm{mm})\end{array}$ & $\begin{array}{c}\text { Percolation } \\
(\mathrm{mm})\end{array}$ & $\begin{array}{c}\text { Water Consumption } \\
(\mathrm{mm})\end{array}$ & $\begin{array}{c}\text { Evapotranspiration } \\
(\mathrm{mm})\end{array}$ \\
\hline S1 & 253.0 & 440.0 & 277.0 & 204.2 & 958.0 & 753.8 \\
\hline S2 & 90.0 & 820.0 & 248.0 & 161.2 & 789.1 & 627.9 \\
\hline
\end{tabular}




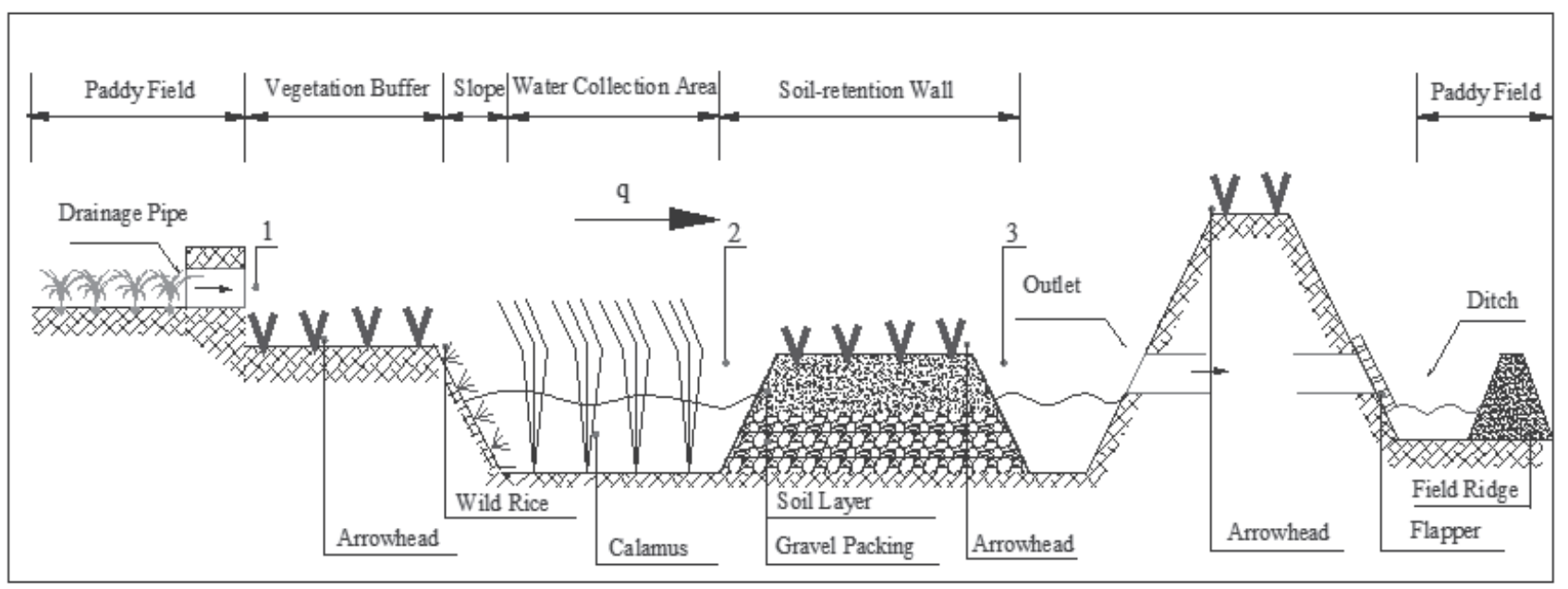

Fig. 2. Side view of the the soil-vegetation buffer strips system.

was treated through natural decomposition of pollutants before flowing into the drainage ditch.

The soil-vegetation buffer strips were composed of four parts: a vegetation buffer, slopes (plant filter), a water collection area, and a soil-retention wall. In this soilvegetation buffer strips, considering the plant's economic value, strong nitrogen and phosphorus absorption capacity, and the rational allocation of emergent vegetation and floating plants, calamus (Acorus calamus L.) in the water collection area and arrowhead (Sagittaria trifolia) in the vegetation buffer were matched together to remove pollutants. When referring to the slopes, the main function was filtration, thus wild rice (Zizania aquatica) was chosen for planting to remove particulate pollutants, with the slope gradient of 1:1. In the water collection area, the main vegetation feature was deep-rooted and emergent, like calamus (Acorus calamus L.). Then, the soil-retention wall was designed as a ladder type, with gravel packing on the bottom in a layer about $30 \mathrm{~cm}$ thick and with a $30 \mathrm{~cm}$ thick soil layer on top. The gradient for the soilretention wall was $0.5: 1$, and was designed this way to provide structural stability. This structure was designed just like a subsurface flow wetland, which has a better sewage processing capacity. In addition, the vegetation type above was primarily roots, bulbs, or seed plants, like arrowhead (Sagittaria trifolia). Under this structure, polluted water can remain in the wall for a while, ensuring enough time for adsorbing and removing pollutants, mainly in dissolution state.

After passing through the soil-vegetation buffer strips, water was collected into a ditch, which is separated by a field ridge, before entering the rivers and lakes. A board was set at the outlet to control drainage into the ditch. The side view of this purification system is shown in Fig. 2. Furthermore, the treated water can also flow into a pond for storage for other purposes such as being reused for irrigating the next crop field when needed if the quality can reach the national irrigation water standard. As shown in Fig. 3, water in the pond can be pumped through the water pipes after being filtered whenever needed, which could be a kind of agricultural-drained water treatment and reuse system. A photo of the study area is displayed in Fig. 4.

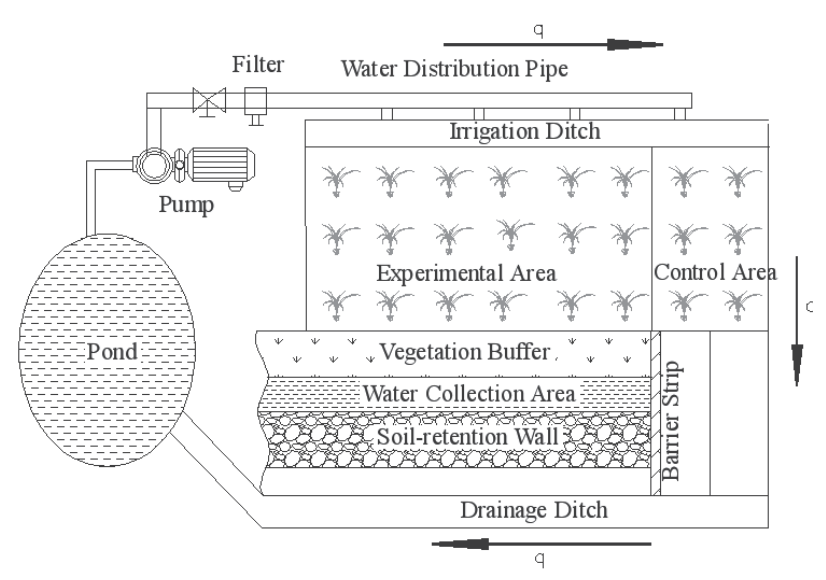

Fig. 3. Top view of the purification and recycling system.

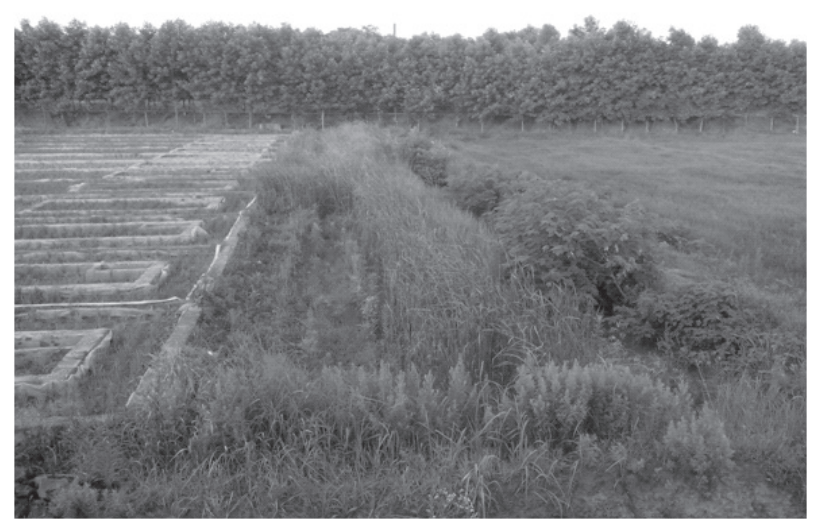

Fig. 4. Photo of the study area. 


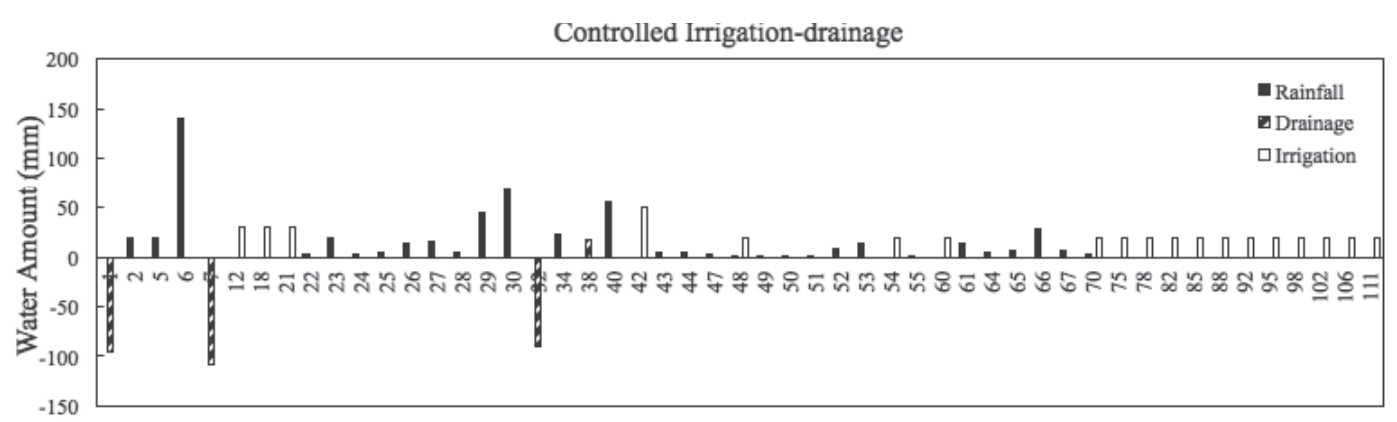

Day after transplantation (2012)

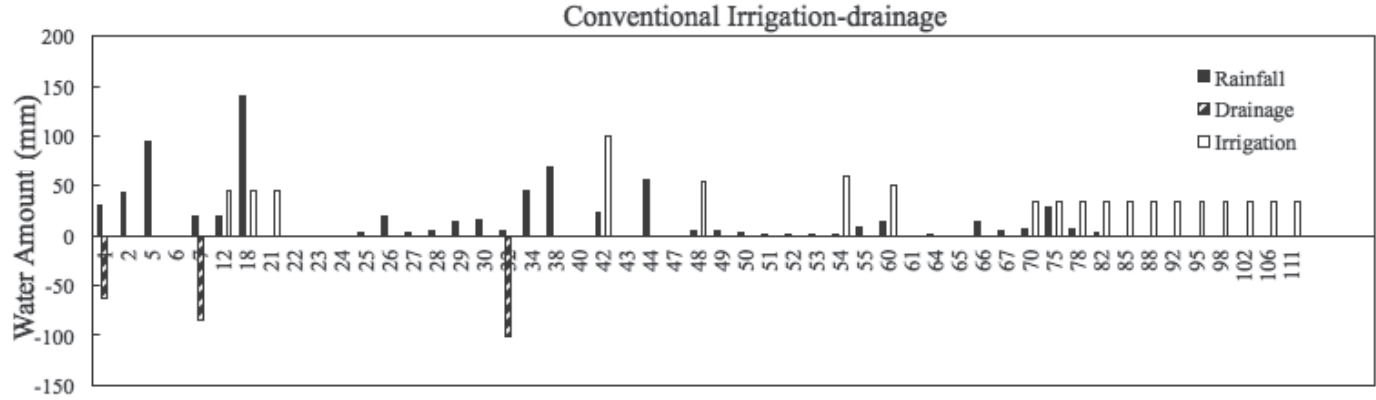

Day after transplantation (2012)

Fig. 5. Rainfall received and irrigation and drainage applied in the entire rice growth period.

\section{Sampling Methods and Data Analysis}

Considering fertilizer applications and rainfall factors, concentrations of nitrogen (total nitrogen and dissolved nitrogen) and phosphorus (total phosphorus and dissolved phosphorus) pollutants from paddy field surface drainage were monitored to study the effect of the soil-vegetation buffer strips system. For the experimental area, sampling sites (1, 2, and 3) are shown in Fig. 2, while for the control area only one site was monitored for comparison.

Ultra-violet spectrophotometry was used to determine total nitrogen (TN) and dissolved nitrogen (DN) levels. In addition, the antimony molybdenum spectrophotometry method was used to determine total phosphorus (TP) and dissolved phosphorus (DP) levels, according to the water and wastewater monitoring analysis method [27].

Statistical analysis of the experimental data of this study was carried out in SPSS 19.0 software.

\section{Results and Discussion}

\section{Pollutant Amount Change with Two Irrigation-Drainage Treatments}

Since a paddy field's surface drainage significantly contributes to agricultural non-point pollution, and the main cause of surface drainage is rainfall, the rainfall amount during the entire rice growth period in 2012 was measured by an SM1-1 rainfall recorder. The amounts of irrigation, drainage, and rainfall along with the experimental period are shown in Fig. 5.

As described above, after the rain, drainage occurred through the drainage pipe in the paddy field. The discharge was measured by a water meter and then converted to water depth over the field. Since the paddy field drainage was a continuous process and pollutant concentration in discharge varied with time, the pollution discharge amount can only be estimated with the average discharge and instant pollutant concentration. We designed two drainage

Table 3. Estimated pollution discharge amount in each treatment

\begin{tabular}{|c|c|c|c|c|c|c|c|c|c|c|}
\hline \multirow{2}{*}{ Drain Time } & \multirow{2}{*}{ Treatment } & \multirow{2}{*}{$\begin{array}{l}\text { Discharge } \\
(\mathrm{mm})\end{array}$} & \multicolumn{2}{|c|}{$\mathrm{TN}$} & \multicolumn{2}{|c|}{ DN } & \multicolumn{2}{|c|}{$\mathrm{TP}$} & \multicolumn{2}{|c|}{ DP } \\
\hline & & & $\mathrm{PC}$ & TPD & $\mathrm{PC}$ & TPD & $\mathrm{PC}$ & TPD & $\mathrm{PC}$ & TPD \\
\hline \multirow{2}{*}{$1 \mathrm{st}$} & $\mathrm{S} 1$ & 108 & 10.6 & 11.4 & 6.26 & 6.8 & 0.52 & 0.6 & 0.36 & 0.4 \\
\hline & S2 & 85 & 12.5 & 10.6 & 6.44 & 5.5 & 0.56 & 0.5 & 0.4 & 0.3 \\
\hline \multirow{2}{*}{ 2nd } & $\mathrm{S} 1$ & 90 & 3.6 & 3.2 & 2.04 & 1.8 & 0.11 & 0.1 & 0.113 & 0.1 \\
\hline & S2 & 101 & 4.8 & 4.8 & 2.54 & 2.6 & 0.20 & 0.2 & 0.125 & 0.1 \\
\hline
\end{tabular}

Note: $\mathrm{PC}$ is the abbreviation for pollutant concentration $\left(\mathrm{mg} \mathrm{l}^{-1}\right)$, and TPD is the abbreviation for total pollutant discharge $\left(\mathrm{kg} \mathrm{hm}^{-2}\right)$. 
processes to compare the two irrigation-drainage modes. The first one (June 26, 2012) was the first day after the rain and the pollutant amount was higher at this time due to fertilization, vs. the second one (July 21, 2012), after another rain event and the pollutant amount was lower. According to soil moisture controlling targets in Table 1, it is necessarily to drain for both. The estimated pollutant discharges from the paddy field are shown in Table 3.

As summarized in Table 3, the pollutant discharge amounts of total nitrogen (TN), dissolved nitrogen (DN), total phosphorus (TP), and dissolved phosphorus (DP) for controlled irrigation-drainage management was a little higher than that for conventional irrigation-drainage management at the beginning, whereas the results were opposite a few days later. It also showed that the controlled irrigation-drainage treatment can reduce pollution by reducing discharge amount compared to conventional irrigation-drainage management. This was consistent with our previous studies [28].

\section{Pollutant Concentration Changes through Soil-Vegetation Buffer Strips}

Basal fertilizer was applied on 20 June 2012. After that, it rained continuously in the following week, which formed a pollutant transport process that is typical for a rain event. We took the same amount of water sample in different sites for analysis, thus we only studied pollutant concentration changes of total nitrogen (TN), dissolved nitrogen (DN), total phosphorus (TP), and dissolved phosphorus (DP) in the field's surface water, obtaining the results shown in Fig. 6 to Fig. 9.

When there was a heavy rain, and the paddy field water table exceeded the controlling line, field drainage was needed. Water from the drainage pipe would get into the water environment directly through surface drainage. In this study, the big rain event on 25 June 2012 was used as an example for observing the function of the soilvegetation buffer strips. Overall, the concentrations of TN, DN, TP, and DP decreased across all treatments after the soil-vegetation buffer strips. The pollutant concentrations for all treatment were reduced to a lower level in a short amount of time, as compared to the natural decomposition for the control areas (CK).

\section{TN Change}

As for the controlled irrigation-drainage treatment shown in Fig. 6a, after the drained water passed the buffer strips, the removal rate of $\mathrm{TN}$ reached $90.6 \%$, while the conventional irrigation-drainage treatment shown in Fig. $6 \mathrm{~b}$ reached $95.2 \%$. It seems that the buffer strips have a better qualification capacity with the conventional irrigation-drainage treatment. As for control area (CK1 and $\mathrm{CK} 2$ ), the removal rates of $\mathrm{TN}$ were $52.0 \%$ and $56.3 \%$, respectively, which were obviously lower.

Specifically, for sampling site 1, after 10 days, the decreasing rates of $\mathrm{TN}$ concentration were $56.6 \%$ and $53.6 \%$ for S1 and S2, respectively; $62.3 \%$ and $65.6 \%$ for sampling site 2 ; and $65.5 \%$ and $68.1 \%$ for sampling site 3. Apparently, after the soil-retention wall, it decreased sharply compared to after the vegetation buffer and water collection area. This indicated that with the gravel packing and soil layer in the wall, TN could be effectively removed compared to the vegetation effect, because the soil-retention wall could extend the residence time of the polluted water, which was favorable for removing nitrogen. Also, regarding the soil-retention wall, TN concentrations increased a little on the second day due to the pollutants getting into the waters through the soil-retention wall. However, the concentrations quickly returned to the former level by the next day. Compared with the natural decomposition in control area, the results in sampling site 1 showed that the arrowhead could remove total nitrogen to a certain extent, though it was not as good as the calamus and the gravels.

\section{DN Change}

As displayed in Figs $7 \mathrm{a}$ and $\mathrm{b}$, the decreasing rates of dissolved nitrogen (DN) after treatment reached 92\% and $90.7 \%$ for controlled (S1) and conventional (S2)
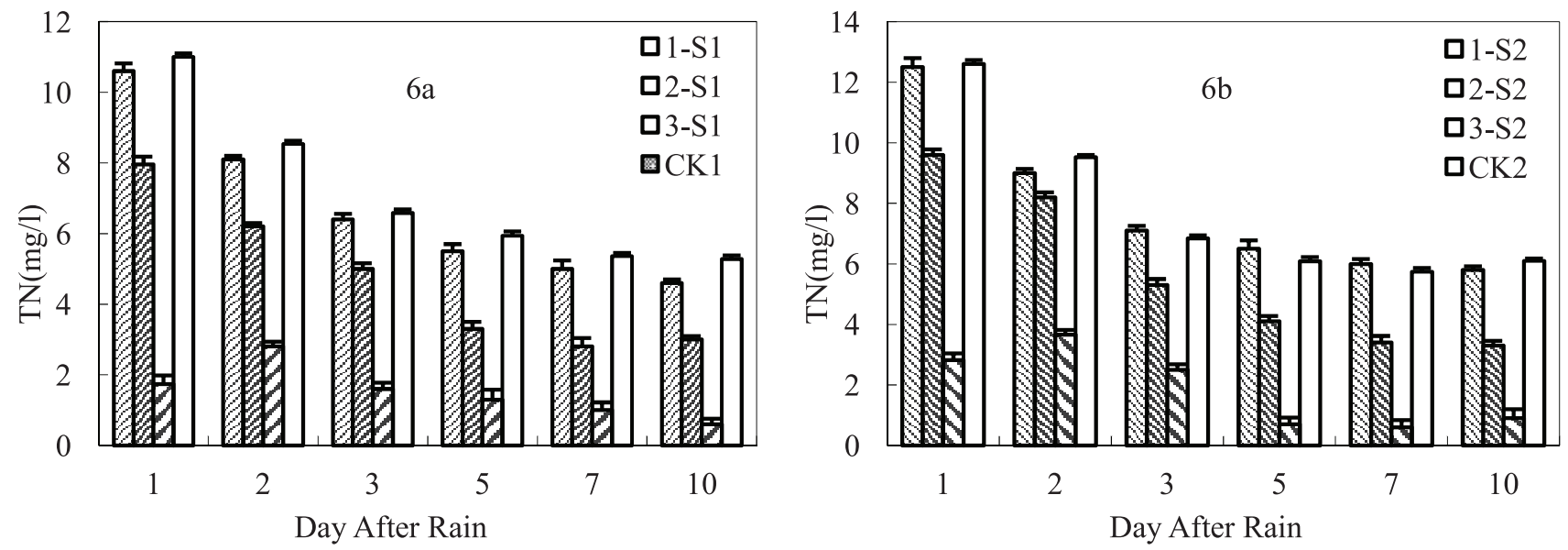

Fig. 6. TN concentration change. 

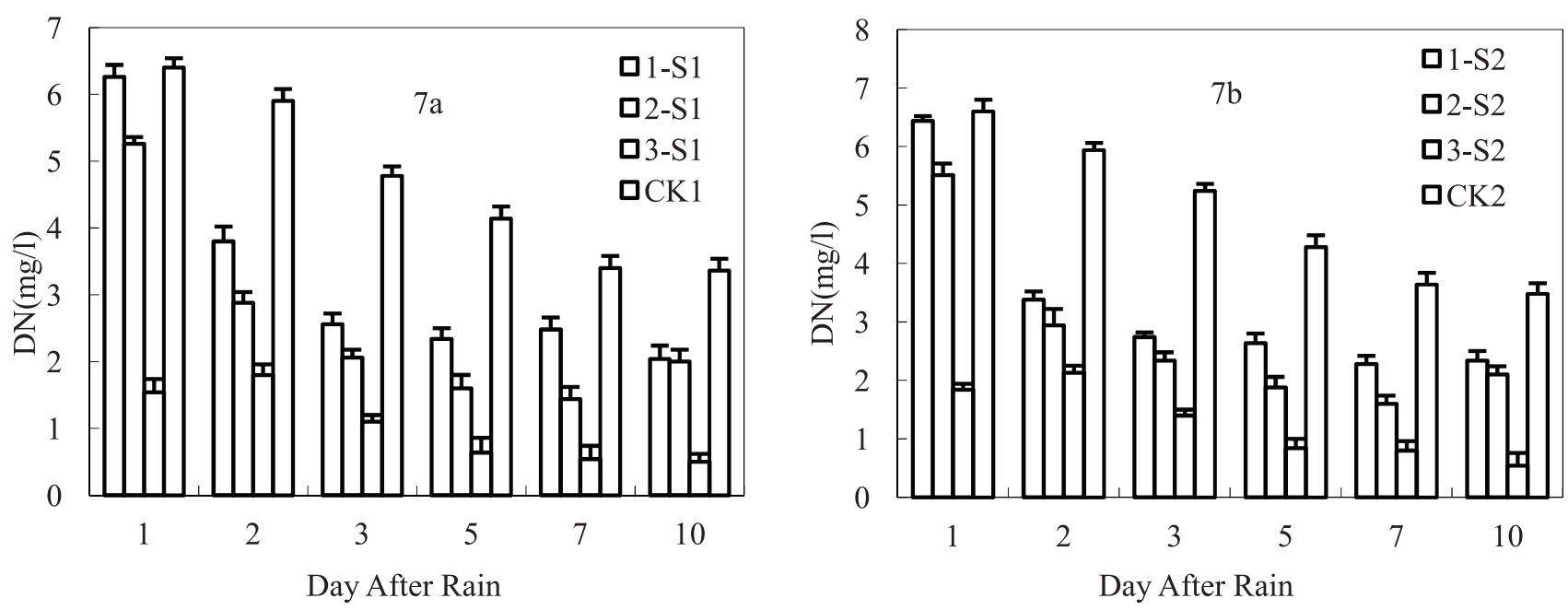

Fig. 7. DN concentration change.

irrigation-drainage management, respectively, while for control areas (CK1 and CK2), the results were $47.5 \%$ and $47.3 \%$.

For three sampling sites, the $\mathrm{DN}$ concentration changes were different. In site 1, the decreasing rates for $\mathrm{S} 1$ and S2 after 10 days were $67.4 \%$ and $63.7 \%$, respectively. In parallel, in site 2 , they were $62.0 \%$ and $61.9 \%$ as well as $67.5 \%$ and $70.7 \%$ in site 3 , respectively. From the results we observed the DN concentration decreased more significantly after the soil-retention wall compared to after the vegetation buffer, which suggested that the vegetation in the water collection area and the slope can absorb DN less efficiently than the gravels.

Compared with TN's decreasing trail, the DN concentration decreased faster in the vegetation buffer, which indicated that the arrowhead can absorb dissolved nitrogen much more easily than undissolved nitrogen. Then DN concentration decreased a little slowly after the vegetation buffer, while the TN decreased faster. That was mainly due to the natural decomposition of undissolved nitrogen in the water collection area. However, DN concentration was decreasing more sharply after the soil-retention wall, which was attributed to the strong absorption ability of the soil layer and gravel on dissolved nitrogen.

\section{TP Change}

Generally, the removal rates of TP after 10 days were $94.2 \%$ and $92.9 \%$ for S1 and S2 treatments, respectively, while for control treatments CK1 and CK2 the results were $55.1 \%$ and $56.8 \%$, respectively (Fig. 8).

As for sampling site 1, the decreasing rates for S1 and S2 were $71.2 \%$ and $64.3 \%$, respectively, and for sampling site 2 they were $66.7 \%$ and $66.3 \%$. In terms of sampling site 3 , they were $66.1 \%$ and $66.5 \%$, respectively, which obviously suggests that TP can be removed much more effectively compared with the TN discussed above mainly due to the strong absorption ability of the arrowhead on phosphorus. Further, in this purification system, the undissolved phosphorus could be settled as sediment in the water collection area through natural decomposition
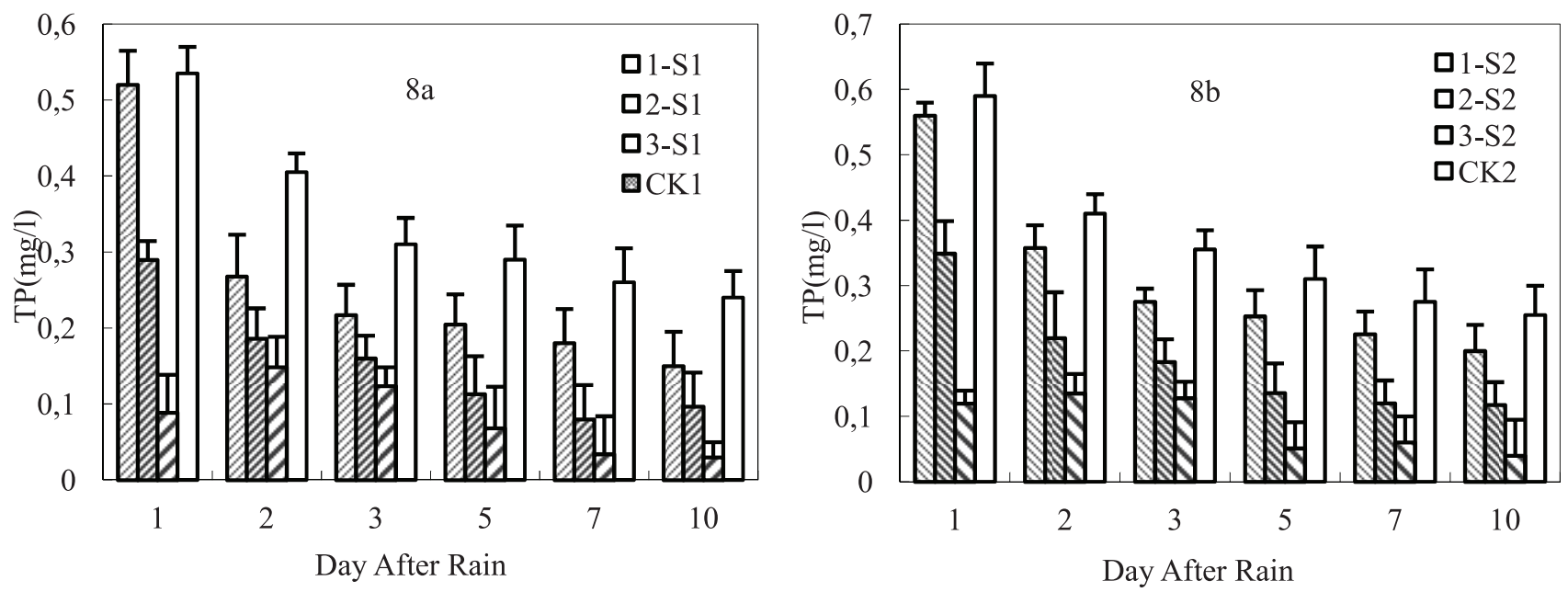

Fig. 8. TP concentration change. 


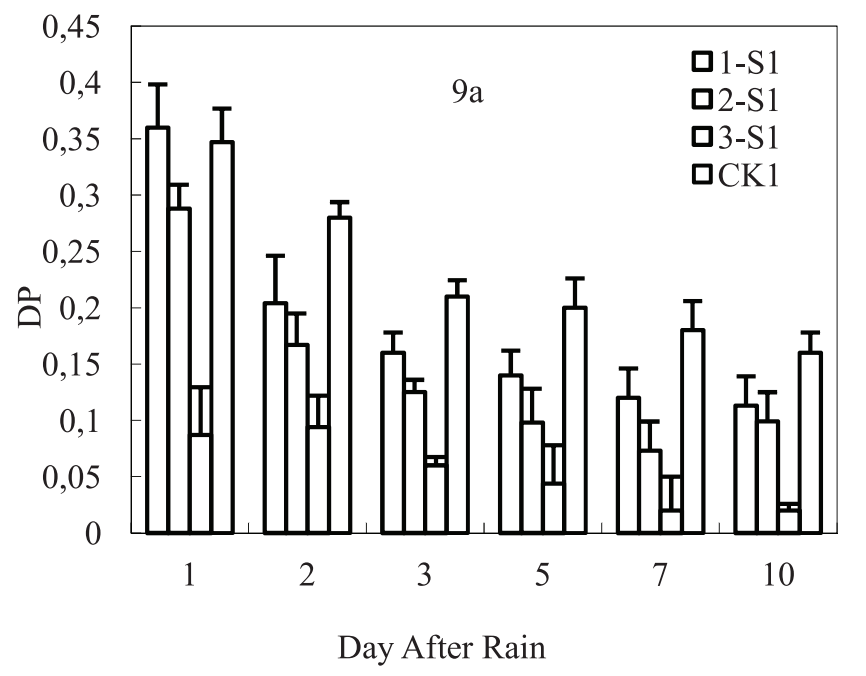

Fig. 9. DP concentration change.

like undissolved nitrogen did. Combining this factor with the soil-retention wall effect on phosphorus, there was little difference on the TP removal effects between the slopes and soil retention wall, which could be illustrated from the results obtained above.

\section{DP Change}

In general, after the buffer strips, DP removal rates were $94.4 \%$ and $95 \%$, respectively, for treatments S1 and S2, while they were $53.9 \%$ and $53.6 \%$ for treatments CK1 and CK2, respectively (Fig. 9).

Referring to sampling site 1 , the removal rates for $\mathrm{S} 1$ and S2 were $68.6 \%$ and $68.8 \%$, respectively; for sampling site 2 , they were $65.6 \%$ and $68.4 \%$, respectively; and for sampling site 3 , they were $77.0 \%$ and $77.8 \%$, respectively.

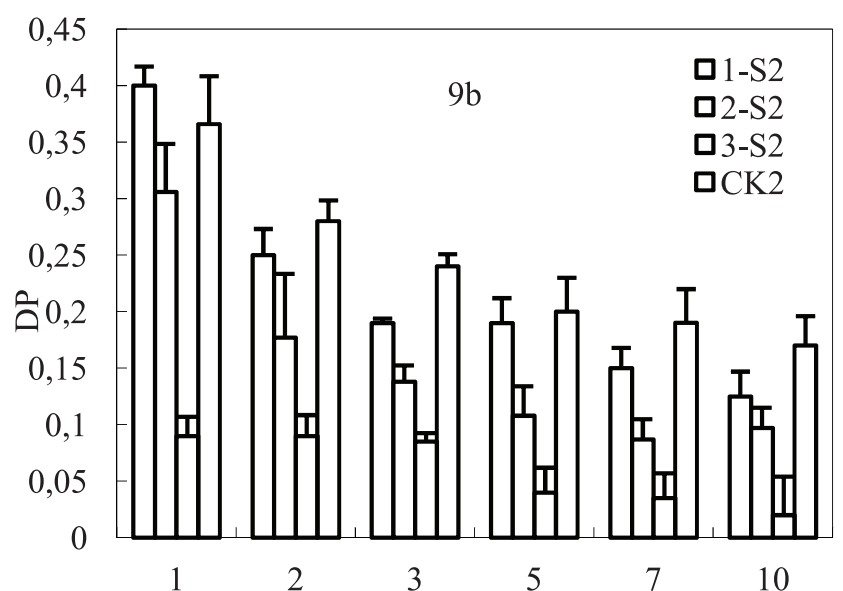

Day After Rain

As the data show, DP was absorbed much more through soil and gravel rather than vegetation, thus it was decreasing sharply after the soil retention wall. However, the TP decreasing rates did not change much. Thus we may draw the conclusion that undissolved phosphorus was mainly intercepted at the vegetation buffer or the slope or water collection area.

\section{Water Quality Evaluation Results of the Buffer Strips}

Tables 4 and 5 illustrate the evaluation of water quality classification standards and the relevant grade based on the national standard in China [29], which represent that each parameter is graded and given a certain score. The water quality is evaluated with the total score for all items.

Table 4. Evaluation of water quality classification standard.

\begin{tabular}{|c|c|c|c|c|c|c|c|c|c|c|c|c|}
\hline \multirow{3}{*}{ Item } & \multicolumn{12}{|c|}{ Surface Water Quality Standard } \\
\hline & \multicolumn{2}{|c|}{ (I) } & \multicolumn{2}{|c|}{ (II) } & \multicolumn{2}{|c|}{ (III) } & \multicolumn{2}{|c|}{$\begin{array}{l}\text { Mild Pollution } \\
\text { (IV) }\end{array}$} & \multicolumn{2}{|c|}{$\begin{array}{l}\text { Medium Pollution } \\
\text { (V) }\end{array}$} & \multicolumn{2}{|c|}{$\begin{array}{l}\text { Strong Pollution } \\
\text { (VI) }\end{array}$} \\
\hline & $\begin{array}{l}\text { Dividing } \\
\text { Line }\end{array}$ & Score & $\begin{array}{l}\text { Dividing } \\
\text { Line }\end{array}$ & Score & $\begin{array}{l}\text { Dividing } \\
\text { Line }\end{array}$ & Score & $\begin{array}{l}\text { Dividing } \\
\text { Line }\end{array}$ & Score & $\begin{array}{l}\text { Dividing } \\
\text { Line }\end{array}$ & Score & $\begin{array}{l}\text { Dividing } \\
\text { Line }\end{array}$ & Score \\
\hline $\mathrm{TN}$ & $\leq 0.2$ & 10 & $\leq 0.5$ & 9 & $\leq 1.0$ & 8 & $\leq 1.5$ & 6 & $\leq 2.0$ & 3 & $>2.0$ & 1 \\
\hline $\mathrm{TP}$ & $\leq 0.02$ & 10 & $\leq 0.1$ & 9 & $\leq 0.2$ & 8 & $\leq 0.3$ & 6 & $\leq 0.4$ & 3 & $>0.4$ & 1 \\
\hline $\mathrm{DN}$ & $\leq 0.015$ & 10 & $\leq 0.5$ & 8 & $\leq 1.0$ & 6 & $\leq 1.5$ & 4 & $\leq 2.0$ & 2 & $>2.0$ & 1 \\
\hline
\end{tabular}

Notes:

1. Unit of Dividing Line is $\mathrm{mg} / \mathrm{L}$, and it is from "Surface Water Quality Standards" (GB3838-2002)

2. Polluted Water Quality Classification is from the book Environmental Assessment Study under Zhang Zheng's general editorship (2004).

Table 5. Water quality and the relevant grade.

\begin{tabular}{|c|c|c|c|c|c|c|}
\hline Level & I & II & III & IV & V & VI \\
\hline Total Score of TN, DN and TP & $26 \sim 27$ & $23 \sim 25$ & $17 \sim 22$ & $11 \sim 16$ & $3 \sim 10$ & $1 \sim 2$ \\
\hline
\end{tabular}


Table 6. Evaluation results of the purification and recycling systems.

\begin{tabular}{|c|c|c|c|c|c|}
\hline Item & Treatment & DN & $\mathrm{TN}$ & $\mathrm{TP}$ & Total Score \\
\hline After Fertilization and Rain (mg/L) & \multirow{2}{*}{$\mathrm{S} 1$} & 0.5 & 0.6 & 0.03 & \\
\hline Score & & 8 & 8 & 9 & 25 \\
\hline After Fertilization and Rain (mg/L) & \multirow{2}{*}{ S2 } & 0.5 & 1.1 & 0.04 & \\
\hline Score & & 8 & 6 & 9 & 23 \\
\hline After Fertilization and Rain (mg/L) & \multirow{2}{*}{ CK1 } & 3.4 & 5.3 & 0.24 & \\
\hline Score & & 1 & 1 & 6 & 8 \\
\hline After Fertilization and Rain (mg/L) & \multirow{2}{*}{ CK2 } & 3.5 & 6.1 & 0.26 & \\
\hline Score & & 1 & 1 & 6 & 8 \\
\hline
\end{tabular}

The results shown in Table 6 summarized that the water quality of the paddy field drainage through the vegetation buffer and soil-retention wall could reach Class II for both conventional and controlled irrigation-drainage after a rain event, while reaching only Class V in control areas without the treatment system. All of the treated water drained from the paddy field through the system could be used for irrigation according to the national standard for irrigation quality [30]. What should be noticed was that this system was the last step before drained water entering the water environment. We can reuse the drained water with nutrients for irrigation without a doubt. The table also implied that agricultural pollution from paddy fields was serious in southern China. Without treatment, the pollutants will contaminate the surface and groundwater environments, resulting in unsafe drinking water issues.

\section{Conclusions}

This study constructed soil-vegetation buffer strips for paddy field agricultural drainage water treatment and reuse, a method that is promising to reduce nonpoint pollution from agriculture in southern China. By comparison with controlled irrigation-drainage and conventional irrigation-drainage techniques, we can conclude there was pollution-reducing potential for controlled irrigation-drainage measurement. The experiment results furtherly demonstrated that, exploiting the soil-vegetation buffer strips, nitrogen and phosphorus in the field surface drainage were dramatically reduced for both irrigation-drainage methods, mainly via plant absorption and the system's physical filtration, compared with the natural decomposition in control areas. Total nitrogen and phosphorus decreased, primarily through sediment and vegetation absorption, while dissolved nitrogen and phosphorus levels decreased mainly through soil and gravel adsorption. With the soil-retention wall, the polluted water could remain in the wall for a longer period of time, allowing enough time for the process of polluted water treatment.

The assessment of the treated water indicated that the drained water from the paddy field was purified, and its quality could reach class II for conventional and high fertilizer levels after a typical rain event, satisfying the national standards for farmland irrigation. With this system, agricultural pollutants could be effectively removed before entering the water environment. Finally, our results suggest the possibility of agricultural water reuse, which represents a meaningful step for agricultural water management in southern China.

\section{Acknowledgements}

This work was funded partly by the Research Project of Special Scientific Funds in Public Service Sectors (Water Conservancy) (201001040, 201301017), partly by Fundamental Research Funds for the Central Universities (2014B37714, 2014B04814, 2015B05814), partly by Water Conservancy Science and Technology Project of Jiangsu Province (2013073) and partly by the National Natural Science Fund (No.51409124), the Natural Science Foundation of Jiangsu Province (No.BK20140564).

Also, the first author thanks China Scholarship Council for its support to allow the author to conduct collaborative research at Texas A\&M AgriLife Research Center. The first and third authors also appreciate the support in part by National Institute of Food and Agriculture (NIFA) Hatch Project (1007968) of the United States Department of Agriculture.

\section{References}

1. CAO Z.H., LIN X.G., YANG L.Z., HU Z.Y., DONG Y.H., YIN R. Ecological Function of "Paddy Field Ring" to Urban and Rural Environment II. Characteristics of Nitrogen Accumulation, Movement in Paddy Field Ecosystem and Its Relation to Environmental Protection. Acta Pedologica Sinica. 43 (2), 256, 2006.

2. CAI L.Y., LI Y., ZHENG Z.H. Temporal and Spatial Distribution of Nitrogen and Phosphorous of Lake Systems in China and Their Impact on Eutrophication. Earth and Environment. 38 (2), 235, 2010.

3. SHARPLEY A.N., MCDOWELL R.W., KLEINMAN P.J.A. Phosphorus Loss from Land to Water: Integrating 
Agricultural and Environmental Management. Plant Soil, 237, 287, 2001.

4. XIE Y.X., XIONG Z.Q., ZHAO X., XING G.X., GUO T.C. Contribution of Nitrogen and Phosphorous on Eutrophied Irrigation Water in a Paddy Soil: a Case Study in Taihu Lake Region. Acta Ecologica Sinica. 28 (8), 3618, 2008.

5. POE G.L., SCHULZE W.D. Final Report: An Experimental Economics Examinations of Incentive Mechanisms for reducing Ambient Water pollution Levels from agricultural Non-point Source Pollution. http://cfpub.epa.gov/ ncerabstracts/index.cfm/fuseaction/display.abstractDetail/ abstract/6237/report/F, 2009.

6. WU M.S., HONG L. Design of Virtual Experiment Based on Agricultural Drainage and Nitrate loss. Journal of Wuhan University. 45 (3), 305, 2012.

7. ZHU X.D. Study on River Pollution and Restoration Countermeasure in Taihu Basin. Environmental Protection. 1, 43-44, 2006.

8. ZHU Z.L., SUN B. Study on Current Situation, Reasons and Control Measures of Non-point Pollution in China. Chinese Agricultural Science Bulletin. 24 (supplement), 1, 2008.

9. CHEN H.S., SONG X.F., ZOU G.Y. Integrated Management of the Water Environment and Ecological Restoration in Taihu Basin. Water Conservancy and Hydropower Science and Technology Progress. 28 (3), 762008.

10. WANG S.L. Advancement of Study on Farmland Drainage Technology and Based on Water Environment Protection. Journal of Hydraulic Engineering. 41 (6), 697, 2010.

11. WANG Y., WANG J.G., LI W., BO L.J., YANG L.Z. Comparisons on Interception Effect of $\mathrm{N}$ and $\mathrm{P}$ of Three Kinds of Agricultural Drainage Canals. Soils. 41 (6), 902, 2009.

12. YANG L.Z., ZHOU X.P., WANG J.G., WANG D. J., SHI W.M., SHI L.X. Study on Vegetative Filter Channel System of Agricultural Non-point Pollution Control and the Effect. Chinese Journal of Ecology. 24 (11), 1371, 2005.

13. YU H.B., XI B.D. Effect of Rainfall Runoff on Nitrogen and Phosphorus Loss in Farming Drainage Ditch. Research of Environmental Sciences. 22 (4), 409, 2009.

14. DING J.L., PENG S.Z., XU J.Z., LI D.X. Experimental Study on Evapotranspiration and Crop Coefficient of Rice under Controlled Irrigation. Journal of Hohai University (Natural Sciences), 34 (3), 239, 2006.

15. PENG S.Z., XU J.Z., HUANG Q., LIU F.L. Controlled Irrigation of Paddy Rice and Environmental Multifunctionality. Journal of Shenyang Agricultural University, 35 (5-6), 443, 2004.

16. PENG S.Z., HAO S.R., ZHU C.L., LIU Y., XU N.H. Exemplary and Application of Controlled Irrigation on Rice in Ningxia Irrigation Zone. Chinese Hydraulic Engineering Society 2000 Annual Conference Proceedings: Water Saving Irrigation, 295, 2000.

17. LI Y. Y., SHAO X.H., TAN J.Y., HU X.J., ZHOU J., WANG J.L., LU S.G., XU H.L. Effects of controlled and mid- gathering irrigation on paddy rice height and yield. Journal of Food, Agriculture \& Environment, 10 (3-4), 659, 2012.

18. KOSKIAHO J., EKHOLM P., RATY M., RIIHIMAKI J., PUUSTINEN M. Retaining Agricultural Nutrients in Constructed Wetlands-Experiences under Boreal Conditions. Ecology Engineering. 20, 89, 2003.

19. LIU S.Y. Construction of the Artificial Wetlands Based on the Agricultural Non-point Source Pollution: Example for the Pipa Temple Reservoir. Central South University of Forestry and Technology, 2012.

20. YU Z.M., YUAN X.Y., SHI W.M. The Technology of Constructed Wetlands to Non-point Source Pollution Water Treatment. Chinese Agricultural Science Bulletin. 26 (3), $264,2010$.

21. HERBERT J.B. Application of Constructed Wetlands in Recycling, Agriculture and Agroforestry: Water Management for Changing Flow Regimes. Water and Nutrient Management in Natural and Constructed Wetlands, Chapter 1, 1, 2011.

22. NIKO S., HARRI V., JUKKA L. Vegetation is the Main Factor in Nutrient Retention in a Constructed Wetland Buffer. Plant and Soil, 258, 179, 2004.

23. HAN L.N., LI Y.Y., SHI H., ZOU G. H., YU H.B., XIAO R.L., WU J.S. Study on Comparison of Different Aquatic Plant on Nitrogen and Phosphorus Ecological Control Measures in Drainage Ditch of Farmland in Southern China. Research of Agricultural Modernization. 33 (1), 117, 2012.

24. PARESH L., BILL F. Relationships Between Aquatic Plants and Environmental Factors Along a Steep Himalayan altitudinal gradient. Aquatic Botany. 84, 3, 2006.

25. SARAH J. Effects of Water Level and Phosphorus Enrichment on Seedling Emergence from Marsh Seed Banks Collected from Northern Belize. Aquatic Botany. 79, 311, 2004.

26. YU H.B., XIAO R.L., YANG Z.J., ZHANG S.N., LIU F. Biomass and Effects of Five Aquatic Plants Uptake of Nitrogen and Phosphorus in Ecological Ditch. Journal of Nuclear Agricultural Sciences. 26 (5), 798, 2012.

27. SEPA (State of Environmental Protection Association). Water and Wastewater Monitoring Analysis Method (The Fourth Edition). China Environmental Science Press. Beijing, 243, 2002.

28. LI Y.Y., SHAO X.H., HU X.J., JIN B.B., ZHU G.X. Dynamic Changes of Nitrogen Losses through Drainage with Controlled and Mid-gathering Irrigation during Typical Rainstorm Events in Southern China. Res. on Crops, 14 (4), 1238, 2013

29. SEPA (State of Environmental Protection Association). Environmental Quality Standard for Surface Water. GB38382002, P.R.China, 2002.

30. SEPA (State of Environmental Protection Association). Standards for Irrigation Water Quanlity. GB5084-92, P.R.China, 1992. 